\title{
Management of finishing pastures to maximise carcass gain
}

\author{
D.R. STEVENS and J.D. TURNER \\ AgResearch, Gore Research Station, Private Bag 50022, Gore
}

\begin{abstract}
A bstract
Special-purpose finishing areas must achieve the maximum output of carcass gain to ensure their cost effectiveness. Liveweight and carcass weight gain were measured from lambs finished on Puna chicory (Cichorium intybus)/Hakari upland brome (Bromus sitchensis)/Pawera red (Trifolium prutense) and Huia white clover (Trifolium repens) pasture for periods of 3 to 18 weeks after grazing medium or low quality pastures over two summers at the Gore Research Station. The relationship between growth of lambs and time on finishing pasture was quadratic in year 1 when chicory comprised $37 \%$ of the pasture on offer. Highest live and carcass weight gains were achieved by finishing for between 9 and 18 weeks. In year 2 with a chicory content of $7 \%$ all finishing periods produced similar live weight and carcass weight gains. Carcass gain on low quality pasture (year 2) averaged only $3.5 \mathrm{~g} / 100 \mathrm{~g}$ liveweight gain compared with of $42 \mathrm{~g} / 100 \mathrm{~g}$ liveweight gain and $47 \mathrm{~g} / 100 \mathrm{~g}$ liveweight gain for medium quality and finishing pastures, respectively, averaged over two years. A finishing period of 9 weeks is recommended when chicory levels are high. Increased lamb performance was still evident when chicory content declined. No detrimental fat deuosition was found in faster growing lambs. Skin and wool weights were significantly $(\mathrm{P}<0.05)$ improved through high quality diets.
\end{abstract}

Keywords: carcass weight gains, Cichorium intybus, fat deposition, finishing time, liveweight gain

\section{Introduction}

The use of improved pastures and specialist finishing pastures is a key factor in achieving faster growth and higher target lamb liveweights. Traditionally, high quality pasture has been characterised as that high in white clover (Trifolium repens L.) (Rattray et al. 1987). With the development of improved cultivars of grasses other than perennial ryegrass (Lolium perenne L.) and herbs such as chicory (Cichorium intybus), special purpose finishing pastures can now be sown. Chicory, for example, can give lamb liveweight gains of approximately 300 g/day (Brown 1990; Fraser et al. 1988). Brown (1990) outlined the benefits of achieving improved lamb performance by integrating improved pastures into farming systems but identified several limitations to putting such systems into place on a large scale. One limitation to the use of an integrated herbage system is that specialist species such as chicory, red clover (Trifolium pratense L.) and white clover (Trifolium repens L.) need to be confined to a small part of the farm as their lack of winter activity means increased cool season utilisation on the rest of the farm. The questions therefore become: How do farmers get the maximum economic return from specialist finishing pastures? How do farmers manage finishing pastures to maximise carcass weight gains?

These were the questions addressed by a Meat Research and Development Council funded research programme at the Gore Research Station in Southland. Lambs were finished for short or long periods on a special purpose pasture (chicory/upland brome (Bromus sitchensis)/clover) after being transferred from low (browntop (Agrostis stolonifera) dominant) or medium quality pastures (ryegrass/white clover).

\section{$M$ ethods}

\&specialist finishing_pasture_consisting_of_Grasslands

Hakari upland brome, Grasslands Puna chicory, Grasslands Huia white clover and Grasslands Pawera red clover was used for finishing Coopworth ram lambs at the Gore Research Station in Southland over the two summers of 1991-92 and 1992-93. Lambs grown from weaning on 'medium' and 'poor' pasture were slaughtered at 3-week intervals over the following 18 weeks. The 'medium' pasture was Grasslands Nui ryegrass and Grasslands Huia white clover pasture. The low quality pasture (included in Year 2 only) consisted of- browntop, crested dogstail; (Cynosurus cristatus) sweet vernal, (Anthoxanthum odoratum) and white clover. Five lambs were slaughtered or transferred for every treatment and replication every 3 weeks. Three replicates of the finishing pasture and one each of the medium and poor quality pastures were used. The trial commenced on 17 December in 1991 and 24 November 1992 with lambs of an average weight of 25 and $21 \mathrm{~kg}$ respectively. Final liveweights were 41 to $51 \mathrm{~kg}$ by the trial end on 21 April 1992 and were 30 to $4.5 \mathrm{~kg}$ by the trial end on 30 March 1993. 
Lambs were transferred from the poor or medium quality pasture to speciality pasture for finishing periods of either 3, 6, 9 or 18 weeks before slaughter. Six groups of lambs were transferred from low and medium pasture to finishing pasture for a 3-week finishing period, three groups for a 6-week finishing period, two groups for a 9-week finishing period and one for an 18-week period during the 18 week trial. Initial carcass weights were taken from a random group of 15 lambs slaughtered at weaning each ye\&. Liveweight was measured after an 18- hour fast. Carcass weight and tissue depth over the 12th rib (GR) were recorded for individual carcasss at the Fortex Silverstream slaughter plant. Skin and wool weights were measured in only year 1 following a standard slipe process on lambs which had been on the individual pasture treatments for 18 weeks.

All lambs were orally drenched with Ivermectin at 3-weekly intervals throughout the trial and were treated with $2 \mathrm{ml}$ of vitamin B 12 (Prolaject) in late January each year after liver tests indicated low storage levels. Selenium was included in the oral drench every six weeks.

Pasture intake was measured by difference between the pre- and post-grazing herbage masses using a Mosaic Industries pasture probe calibrated for each pasture type. The botanical composition of the pastures was assessed by herbage dissection before grazing in both years and after grazing in year 2. Protein and digestibility was assessed by chemical analysis on pasture samples taken to ground level.

Data were analysed by generating separate standard errors for the sum of liveweight gain over the 18 weeks for each series of finishing period to allow within finishing period comparisons. Trends observed due to lengthening finishing periods were analysed by weighted regression using the inverse of the variance as the weighting. Initial slaughter data were used to estimate the starting carcass weights of lambs in order to estimate carcass gain. Final skin and wool weights were adjusted for liveweight using covariate analysis.

\section{Results}

\section{Live and carcass weight gain}

The total liveweight gain of lambs grazing medium or low quality pastures over the 18 week trial was significantly lower than the cumulative liveweight gain achieved by grazing lambs on finishing pastures for any series of finishing periods (Figure 1). The response to increasing length of finishing period was different in both years. Lamb liveweight gain increased as finishing period increased during year 1. This response was quadratic with a predicted peak liveweight gain response for finishing periods between 9 and 18 weeks. In year 2 the response was simplified as each finishing period gave similar gains compared with lambs remaining on low or medium quality pastures. Maximum gains in year 1 were higher than those achieved in year 2. Lambs from medium or low quality pasture achieved similar gains when transferred to finishing pastures.

Figure 1 Total 18-week liveweight gain for lambs grazing medium or low quality pasture (finishing time 0 ) or after grazing finishing pastures for different length periods.

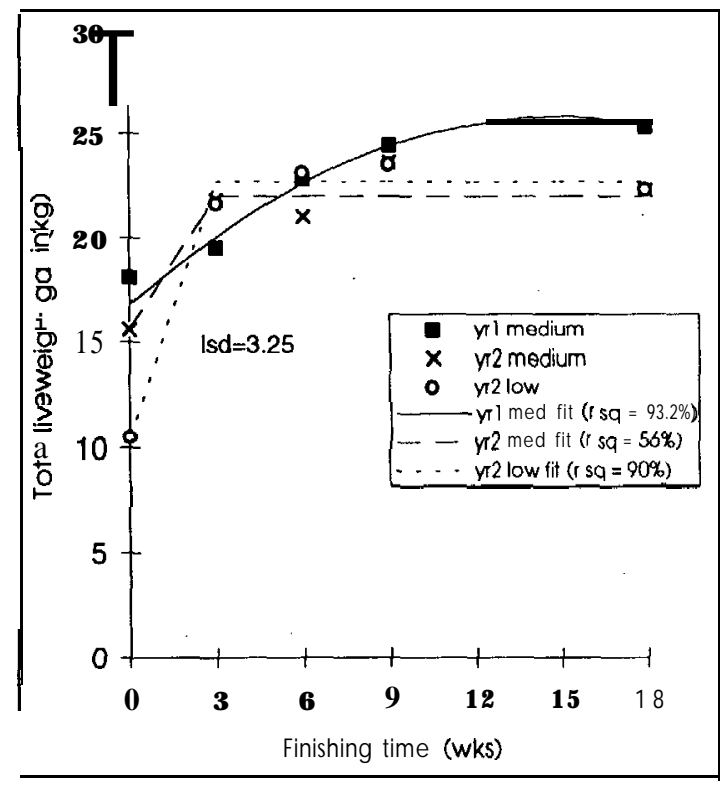

Carcass gains followed a similar pattern to liveweight gains in both years (Figure 2). The efficiency of conversion of live to carcass weight gain was higher in year 1 than year 2 (Table 1) and was higher for lambs being finished than those remaining on medium or low quality pasture.

\section{Tissue depth over of the 12th rib (GR)}

The GR measurement varied with treatment. This was an indicator of liveweight at slaughter rather than an actual treatment effect. Figure 3 shows significant relationships $(\mathrm{P}<0.05)$ between $\mathrm{GR}$ and liveweight for years 1 and 2. In both years GR showed relatively little change until lamb liveweight exceeded $35 \mathrm{~kg}$ after which GR began to increase more rapidly. GR increase was greater in year 1 than year 2 because higher final liveweights were achieved in year 1 . 
Figure 2 Total Id-week carcass weight gain for lambs grazing medium or low quality pasture (finishing time 0 ) or after grazing finishing pastures for different length periods.

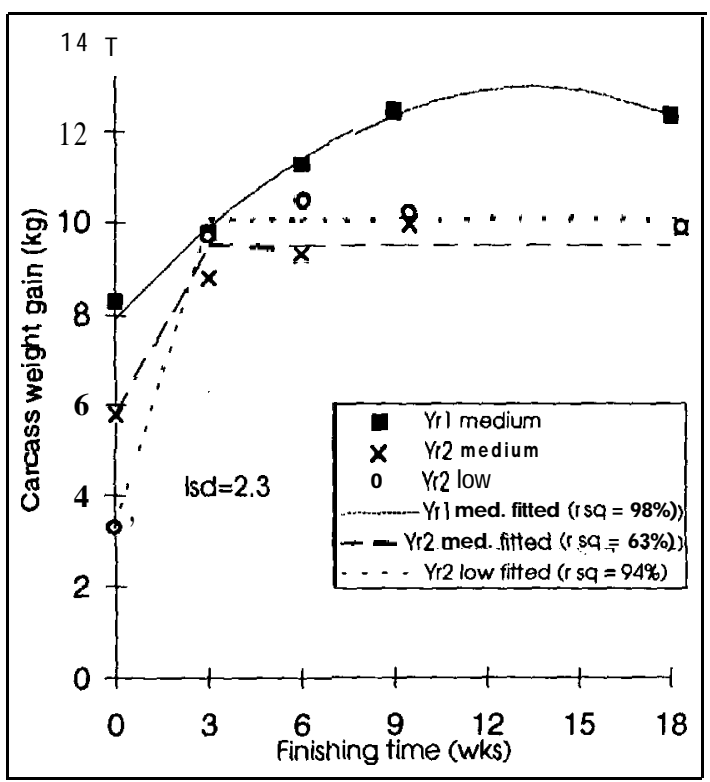

\section{Wool and skin weights}

Lambs that had grazed finishing pasture for 18 weeks from weaning had significantly $(\mathbf{P}<0.05)$ higher wool and skin weights than lambs on medium quality perennial pasture (Table 2).

\section{Pasture allowance and intake}

The herbage mass both before and after grazing (Table 3) was greater for the finishing pasture than for medium or low quality pastures. Similar herbage masses both before and after grazing were achieved in each year. Utilisation levels were similar for lambs on finishing pastures in both years as were the amounts of pasture offered per lamb and the intake of each lamb. The utilisation level of medium quality pasture was higher in year 1 than year 2, however pasture on offer per lamb was lower in year 1 . The intake of lambs on medium quality pasture was similar in both years.

Lambs on low quality pasture (year 2) were introduced to pastures of similar herbage mass as medium quality pastures but the pasture offered per lamb, the intake and the pasture utilization of those lambs was the lowest of all treatments.

\section{Botanical composition}

Botanical composition data (Table 4) show that sown and other grasses in the finishing pasture increased
Figure 3 Relationship between carcass GR and liveweight at slaughter.

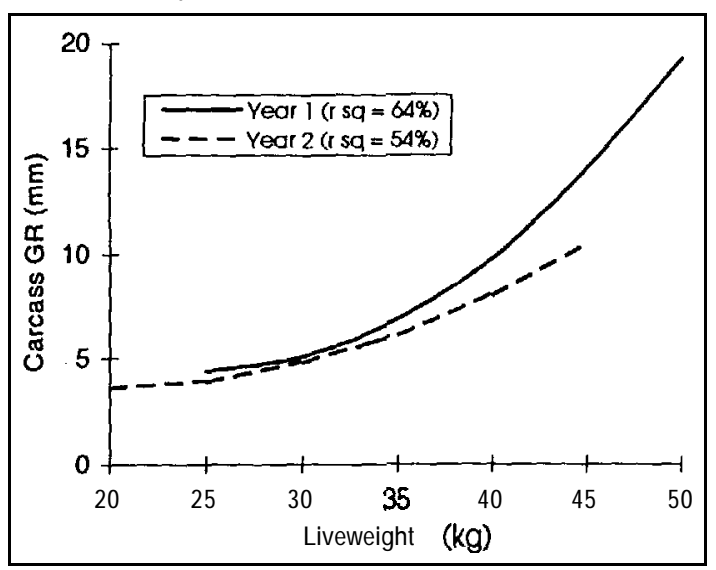

Table 1 Efficiency of conversion of liveweight to carcass weight gain for both Iambs remaining on medium or low quality pasture or finished over $3,6,9$ or 18 weeks (g carcass gain/100 g liveweight gain).

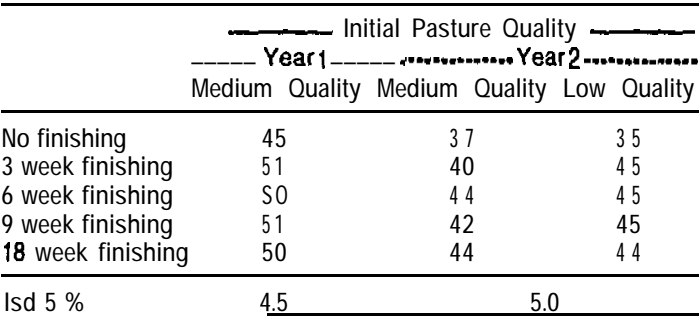

Table 2 Wool and skin weights of lambs continuously finishing or medium quality pastures for 18 weeks after weaning (kg/lamb adjusted for lamb liveweight).

\begin{tabular}{lcc}
\hline & Wool & Skin \\
\hline Finishing & 1.90 & 3.06 \\
Medium Quality & 1.70 & 2.69 \\
& & \\
\hline Isd 5\% & 0.19 & 0.36 \\
\hline
\end{tabular}

from year 1 to year 2. White clover was lower in year 2 in all treatments though the small red clover contribution remained similar in both years. The amount of chicory declined markedly from year 1 to year 2 . Low quality pastures in-year 2 had the lowest sown grass and the highest other grass component as well as the highest component of dead material. The botanical composition after grazing in year 2 showed that the percentage of sown leaf, white clover, chicory and 
red clover all declined during grazing while grass stem, other grasses and dead material increased.

\section{Herbage quality}

Crude protein and digestibility level for January and March, though unreplicated, were similar in both finishing and medium quality pastures in year 1 (Table 5). Finishing pastures had significantly $(P<0.05)$ higher protein and digestibility in January of year 2. In March of year 2 digestibility was similar for all pasture types however the protein level of low quality pasture remained lower than either finishing or medium quality pastures.
Table 3 Pre- and post-grazing herbage mass, pasture utilisation and intakes (mean of 14 grazing periods).

\begin{tabular}{|c|c|c|c|c|c|c|}
\hline & \multicolumn{2}{|c|}{-- Pasture Quality -- } & \multicolumn{4}{|c|}{.......- Pasture Quality ...........- } \\
\hline & Finishing & Medium & Finishing & Medium & Low & $\begin{array}{c}\text { SE } \\
(Y r 2)\end{array}$ \\
\hline \multirow{2}{*}{$\begin{array}{ll}\text { Herbage Mass } & \text { before } \\
\text { (kg DM/ha) } & \text { after }\end{array}$} & 4000 & 3100 & 4100 & 3200 & 3100 & 680 \\
\hline & 2200 & 1000 & 2100 & 1500 & 1700 & 230 \\
\hline Utilisation (\%) & 45 & 66 & 49 & 53 & 40 & 7 \\
\hline $\begin{array}{l}\text { Pasture offered } \\
\text { (kg DM/lamb/day) }\end{array}$ & 3.9 & 2.5 & 3.5 & 3.1 & 2.2 & 0.7 \\
\hline $\begin{array}{l}\text { Intake (kg } \\
\text { DM/lamb/day) }\end{array}$ & 1.0 & 1.7 & 1.6 & 1.5 & 1.2 & \\
\hline
\end{tabular}

Table 4 Pre-grazing botanical composition for finishing, medium and low quality pastures in summer of both years and post-grazing botanical composition for year 2 only.

\begin{tabular}{|c|c|c|c|c|c|c|c|c|c|}
\hline & \multicolumn{2}{|c|}{ Y......- Pasture Quality -.-.-.. } & & \multirow{2}{*}{\multicolumn{2}{|c|}{ „ Finishing -- }} & \multirow{2}{*}{\multicolumn{2}{|c|}{$\begin{array}{c}\text { Pasture Quality } \\
\text {--. Medium -.- }\end{array}$}} & \multirow{2}{*}{\multicolumn{2}{|c|}{ Low mpen }} \\
\hline & \multirow[t]{2}{*}{ Finishing } & \multirow[t]{2}{*}{ Medium } & & & & & & & \\
\hline & & & & Pre & Post & Pre & Post & Pre & Post \\
\hline Sown Grass ${ }^{\prime}$ & 20 & 32 & Leaf & 26 & 14 & 25 & 16 & 14 & 9 \\
\hline & & & Stem & 12 & 31 & 12 & 16 & 5 & 17 \\
\hline Other grass & 8 & 15 & & 22 & 30 & 29 & 45 & 56 & 56 \\
\hline White Clover & 27 & 48 & & 20 & 10 & 29 & 12 & 16 & 3 \\
\hline Red Clover & 6 & & & 9 & 1 & & & & \\
\hline Chicory & 36 & & & 7 & 0 & & & & \\
\hline Dead & 3 & 5 & & 6 & 14 & 6 & 10 & 10 & 15 \\
\hline
\end{tabular}

1 Sown grasses were: Finishing = Hakari, upland brome, Medium \& Low = Nul perennial ryegrass

Sulphur levels measured in year 1 were $0.29 \%$ of the herbage dry matter for medium quality pasture and were $0.34 \%$ of the herbage dry matter in the finishing pasture. Sulphur levels in the chicory component averaged $0.53 \%$.

\section{Discussion}

Lamb liveweight and carcass weight gains varied between years. Liveweight gain and efficiency of conversion of that gain to carcass weight was greater in year 1 than year 2 . This variation is an important feature of pasture based animal finishing enterprises.

Lamb liveweight gain was improved by transferring lambs from low or medium quality pastures to finishing pastures. The overall amount of pasture offered was higher on finishing pastures than on medium or low
Table 5 Crude protein (\% DM) and digestibility (\% DM) of finishing, medium and low quality pastures in January and March.

\begin{tabular}{|c|c|c|c|c|c|c|c|}
\hline & Pasture & $\begin{array}{l}\text { Quality } \\
\text { Year 1 } \\
\text { Finishing }\end{array}$ & $\begin{array}{l}\text { Year } 2 \\
\text { Medium }\end{array}$ & Finishing & Medium & Low & $\begin{array}{c}\text { Isd } 5 \% \\
\text { (Yr } 2 \\
\text { only) }\end{array}$ \\
\hline Protein & $\begin{array}{l}\text { January } \\
\text { March }\end{array}$ & $\begin{array}{l}18.4 \\
25.1\end{array}$ & $\begin{array}{l}16.5 \\
22.6\end{array}$ & $\begin{array}{l}21.9 \\
19.6\end{array}$ & $\begin{array}{l}16.9 \\
20.5\end{array}$ & $\begin{array}{l}13.7 \\
15.3\end{array}$ & 2.6 \\
\hline Digestibility & $\begin{array}{l}\text { January } \\
\text { March }\end{array}$ & $\begin{array}{l}74.3 \\
60.7\end{array}$ & $\begin{array}{l}73.0 \\
79.9\end{array}$ & $\begin{array}{l}70.1 \\
72.5\end{array}$ & $\begin{array}{l}67.4 \\
73.1\end{array}$ & $\begin{array}{l}65.4 \\
71.2\end{array}$ & $\begin{array}{l}1.9 \\
\mathrm{~ns}\end{array}$ \\
\hline
\end{tabular}

quality pasture. Data summarised by Rattray et $a l$. (1987) showed that lamb growth differences once allows exceeded $2 \mathrm{~kg} / \mathrm{hd} /$ day were relatively small and much smaller than those found in this study. Therefore differences are mainly the result of the pasture types rather than the amount offered to each group. The 
digestibility and protein content of the finishing pasture was equal to or better than the other pastures even though higher herbage masses were maintained. The botanical composition data also shows high levels of the quality components of chicory, red and white clovers, particularly in year 1 .

Estimates of the diet composition obtained by combining the year 2 pre- and post-grazing botanical composition and yield data help explain the improved lamb performance on finishing pastures. On finishing pastures the estimated lambs diet consisted of $34 \%$ Hakari leaf, $12 \%$ chicory, $16 \%$ red clover, $27 \%$ white clover and $12 \%$ other species. No Hakari stem or dead material disappearance was evident. On the medium quality ryegrass based pasture the estimated lamb diet was $32 \%$ ryegrass leaf, $43 \%$ white clover and $15 \%$ other grasses. Minor levels of grass stem and dead material disappearance were evident. The estimated lamb diet on the low quality browntop based pasture was $18 \%$ ryegrass leaf, $28 \%$ white clover and $50 \%$ other grasses with a minor dead material intake. Excluding grasses and dead material the lambs on finishing pasture consumed a diet containing 55\% high quality components while lambs on medium and low quality pastures consumed an estimated 43 and 28\% high quality component in their diets respectively. This difference would also have occurred in year 1 as the overall high quality component on offer was 69\% in the finishing pastures and $48 \%$ in the medium quality pasture.

The weight gain response of transferring lambs to finishing pasture variè between years. In year 1 the response was quadratic as increasing finishing period length resulted in greater live and carcass weight gains, peaking between 9 and 18 weeks. Gains in year 2, however, were similar regardless of the length of the finishing period. The major difference in pasture parameters between the two years was a decrease in the amount of chicory in the finishing pasture $(36 \%$ year 1,7\% year 2) and an increase in the grass component. It appears that the lambs needed some time to adjust to the chicory diet before maximising growth. Feed intakes were similar in both years and therefore did not contribute to the differences measured. The growth response of lambs to a change to finishing pasture after grazing poor or medium quality pasture was similar and no compensatory growth was evident.

The efficiency of converting liveweight gain to carcass weight gain was also higher in year 1 than year 2. It was also greater when lambs were grazed on finishing pastures. Detailed examination of the data showed that no relationships existed between liveweight or liveweight gain and conversion efficiency. Therefore it is assumed this was a true effect of growing lambs on finishing pasture. This variation in conversion efficiency between seasons is commented on by many farmers and is a major reason for variations in consistency of supply as lambs take longer to finish in some years. This concept of different rates of finishing is also supported by the relationships between GR and liveweight in Figure 3. The rate of GR increase was different in each year and lower in the same year that conversion efficiency was lower.

The changes in GR with liveweight are typical of growing lambs. Kirton (1983) observed that similar body composition is achieved if similar liveweights are reached regardless of liveweight gain. Parratt \& Young (1983) outlined changes in body composition as liveweight increased and presented a curve similar in shape to those in Figure 3 with the amount of body fat increasing more rapidly after $35 \mathrm{~kg}$ liveweight was reached.

Increases in skin and wool weights were obtained from lambs grazed on finishing pastures, even when adjusted for liveweight. No real conclusions can be drawn about the role of chicory in increasing skin and wool weights as they were measured only in year 1 . The higher levels of sulphur measured in chicory in this trial may indicate high levels of sulphur amino acids which can contribute to an increase in wool growth.

\section{Conclusion}

The use of high quality specialist finishing pastures increased both live weight and carcass weight gain. The conversion of liveweight to carcass gain was also higher with the finishing pasture. When substantial amounts of chicory were present a finishing period of 9 weeks or greater maximised gains and results indicated that an adjustment period was required to maximise gains from chicory based pastures.

\section{ACKNOWLEDGEMENTS}

The authors wish to than the Meat Research and Development Council for their funding of this research; Peter Johnstone for statistical analysis and interpretation; Deborah Allan, Marie Casey and Gordon Baxter for technical assistance and Gore Research Station field staff for trial maintenance.

\section{REFERENCES}

Brown, C. 1990. An integrated herbage system for Southland and South Otago. Proceedings of the New Zealand Grassland Association 52: 119- 122. 
Fraser, T.J.; Cosgrove, G.P.; Thomas, W.J.; Stevens, D.R.; Hickey, M.J. 1988. Performance of Grasslands Puna Chicory. Proceedings of rhe New Zealand Grassland Association 49: 193-196.

Kirton, A.H. 1983. Carcass Composition. Chapter 2: In Lamb Growth. Technical Handbook. Ed. A S Familton, Lincoln College.

Parratt, A.G.; Young, M.J. 1983. Potential growth rates from birth to slaughter. Chapter 1. In: Lamb Growth. Technical Handbook. Ed. A S Familton, Lincoln College.

Rattray, P.V.; Thompson, K.F.; Hawker, H.; Summer, R.M.W. 1987. Pastures for sheep production. Chapter 7. In New Zealand Society of Animal Production Occasional Publication No 10. 